\title{
Aging, inflammation and depressive behavior: a review
}

Adriana Uzoni ${ }^{1,4}$, Ciobanu Ovidiu ${ }^{2,3}$, Elena Raluca Sandu ${ }^{2}$, Ana Maria Buga ${ }^{1,2}$, Aurel Popa-Wagner ${ }^{1,2}$

Department of Psychiatry, University of Medicine Rostock, Germany

Center of Clinical and Experimental Research, University of Medicine and Pharmacy Craiova, Romania

Department of Psychiatry, University Medicine of Saarland, Homburg/Saar, Germany

Department of Biochemistry, University of Medicine and Pharmacy "Victor Babes" Timisoara, Romania

\section{Abstract}

One of the most common co-morbidities of cerebrovascular disorders is neuroinflammation, a hallmark and decisive contributor to many central nervous system (CNS) diseases. Although neuropathological conditions differ in etiology and in the way in which the inflammatory response is mounted, cellular and molecular mechanisms of neuroinflammation are probably similar in aging, hypertension, depression and cognitive impairment or after cerebral insult such as stroke. Moreover, a number of highly prevalent risk factors such as hypertension, diabetes and atherosclerosis are increasingly understood to act as "silent contributors" to neuroinflammation - not only establishing the condition as a central pathophysiological mechanism, but also constantly fuelling it. Mild, but continuous neuroinflammation can provide the ground for disorders such as cerebral small vessel disease (cSVD) and subsequent dementia. Acute neuroinflammation, often in the context of traumatic or ischemic CNS lesions, aggravates the acute damage and can lead to depression, post-stroke dementia and neurodegeneration. All of these sequelae impair recovery and provide the ground for further cerebrovascular events.

\section{Keywords}

Metabolic syndrome; Inflammation; Aging 


\section{Introduction}

Cerebrovascular diseases are among the most prevalent health care problems in Europe. Total European cost of brain disorders in 2010 was 798 billion $€$ of which 64.1 billion $€$ was related to stroke alone [1]. In many cases, the result of cerebrovascular disorders is a loss of independent living and secondary health problems affecting not only patients but also their families. The number of elderly people is increasing with a number of co-morbidities increasing the risk of cerebrovascular diseases [2]. Thus, strategies in guiding patient selection and novel preventive and neuroprotective therapies are urgently needed. Emerging evidence suggest that several diseases show overlapping pathology with neuroinflammation as one possible common mechanism leading to increased risk of cerebrovascular disorders.

In demographically developed countries, the average age at which stroke occurs is around 73 years reflecting the older age structure of these countries. The probability of a first stroke or first transitory ischemic attack is around 1.6 per 1,000 and 0.42 per 1,000, respectively. In less developed regions, the average age of stroke will be younger due to the different population age structure resulting from higher mortality rates and competing causes of death.

Stroke patients are at highest risk of death in the first weeks after the event, and between $20 \%$ to $50 \%$ die within the first month depending on type, severity, age, co- morbidity and effectiveness of treatment of complications. Patients who survive may be left with no disability or with mild, moderate or severe disability. Considerable spontaneous recovery occurs up to about six months [3]. However, patients with a history of stroke are at risk of a subsequent event of around $10 \%$ in the first year and $5 \%$ per year thereafter [4].

The negative consequences of stroke extend well beyond the victims themselves, ultimately including families, caregivers, social networks and employers. The proportion of patients achieving independence in self-care by one year after a stroke ranges from around $60 \%$ to $83 \%$. This wide variation relates to whether the studies are community based or hospital based, which activities are considered in estimating independence, and the methods used to rate ability. In established marked economies (EMEs), depending on the organization of hospital services, between $10 \%$ and $15 \%$ of survivors are resident in an institution at one year [5].

Worldwide stroke it is increasing in parallel with modernization, changes in lifestyle, and the growing elderly population. In particular, rates in Eastern Europe have been increasing, such that currently the highest rates are found in countries such as Bulgaria, Romania, and Hungary. Among the women and men individuals with a low-risk lifestyle (smoking, exercising daily, consuming a prudent diet including moderate alcohol and having a healthy weight during mid-life) had a significantly lower risk of stroke than individuals without a low-risk lifestyle. Therefore the relatively high incidence of stroke may be due in part to the impact of numerous known risk factors in these populations [6] : arterial hypertension, diabetes, high cholesterol, smoking, alcoholism, obesity, stress, and a sedentary lifestyle.

Virtually all drug interventions that have been successful pre-clinically in experimental stroke have failed to translate this success to the clinical setting. We and others propose that this is due to the failure of these pre-clinical studies to fully consider the aging and comorbidities for stroke present clinically [7-9]. It is quite possible that an intervention showing efficacy in a normal animal may not be effective when co-morbidity exists. We have shown that ischemic damage occurs very rapidly in the brain of aged rodents after experimental stroke and that infarct development in aged rats can be slowed down by hypothermia. 


\section{Neuroinflammation in cerebrovascular comorbidities}

Cerebrovascular disease co-morbidities share a similar pathophysiology particularly with respect to neuroinflammation, a hallmark and contributor to many central nervous system (CNS) diseases.

Although neuropathological conditions differ in aetielogy and in the way in which the inflammatory response is mounted, cellular and molecular mechanisms of neuroinflammation are probably similar in aging, hypertension, depression and cognitive impairment or after cerebral insult such as stroke [10]. Moreover, a number of highly prevalent risk factors such as hypertension, diabetes and atherosclerosis are increasingly understood to act as "silent contributors" to neuroinflammation - not only establishing the condition as a central pathophysiological mechanism, but also constantly fuelling it (Figure 1).

Subtle, but continuous neuroinflammation can provide the ground for disorders such as cerebral small vessel disease (cSVD) and subsequent dementia. Acute neuroinflammation, often in the context of traumatic or ischemic CNS lesions, aggravates the acute damage and can lead to a number of pathological such as depression, post-stroke dementia and potentially neurodegeneration. All of those sequelae impair recovery and most of them provide the ground for further cerebrovascular events (Figure 1).

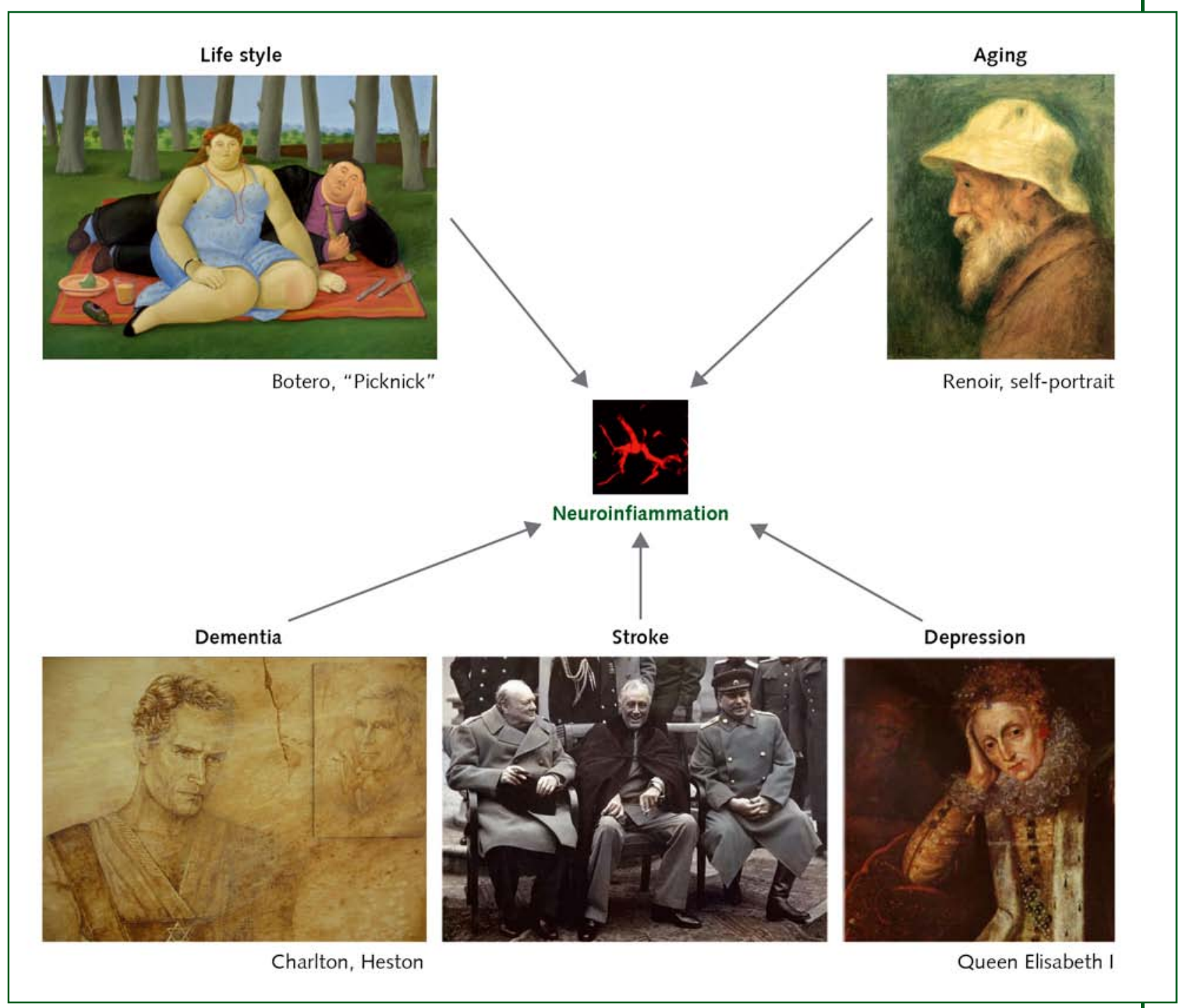

Figure 1. Life style, aging, hypoperfusion and neuroinflammation precipitate neuropsychiatric diseases 


\section{Metabolic inflammation}

It is becoming well established that lifestyle, especially dietary habits, greatly affect metabolic health. Bad nutritional habits can lead to metabolic disorders, triggered by a system-wide chronic inflammation, also called metaflammation, metabolic inflammation [11]. A metaflammation state can lead to a series of disorders and diseases, including hypertension, metabolic syndrome, CVD, stroke, insulin resistance and T2DM. It is postulated that lipid hormones including sphingolipids and eicosanoids in concert with cytokines and adipokines play an important role in this process by inducing adverse regulatory responses in target cells such as macrophages. The role of genetics in driving metabolic disease development is strongly indicated by the higher concordance rate of T2DM in monozygotic than in dizygotic twins. It has been estimated that $30 \%$ to $70 \%$ of T2DM risk can be attributed to genetics [12]. The investigation of gene-environment interactions through large collaborative efforts holds promise in furthering our understanding of the interplay between genetic and environmental factors [13].

\section{Obesity, inflammation and rehabilitation odds in Stroke Patients}

The Obesity paradox has been reported in many articles as a inverse relationship between the body mass index (BMI) and mortality in stroke patients. The relationship between BMI and functional recovery in post stroke patients has not been well described [14-20].

A cohort study from the China National Stroke Registry analysed the relationship between the body mass index (BMI), mortality and post stroke functional recovery at 3 months after disease onset. The study enrolled and analysed 10,905 patients with eligible acute ischemic stroke. Favourable functional recovery was seen in $52,4 \%$ of underweight $\left(\mathrm{BMI}=18,5 \mathrm{~kg} / \mathrm{m}^{2}\right), 55,0 \%$ of normal weight $(\mathrm{BMI}=18,5$ $\left.22,9 \mathrm{~kg} / \mathrm{m}^{2}\right), 61 \%$ of overweight $\left(\mathrm{BMI}=23-27,4 \mathrm{~kg} / \mathrm{m}^{2}\right), 59,2 \%$ of obese $\left(\mathrm{BMI}=27,5-32,4 \mathrm{~km} / \mathrm{m}^{2}\right)$ and $60,3 \%$ of severe obese $(\mathrm{BMI}>32,5 \mathrm{~kg} / \mathrm{m} 2)$ stroke survivors. The overweight AIS survivors had better 3-month functional recovery and moderate obesity showed a protective trend. However, severe obesity was associated with higher mortality and overweight/obesity was not a protective factor of survival at 3 months after stroke [21].

A study on the Effect of Body Mass Index on Stroke Rehabilitation including 819 patients reported that among patients admitted to an acute rehabilitation hospital, overweight patients had better functional progress than did patients in the other weight categories [22].

Still another study on the Obesity Paradox that included 510 TIA survivors, showed that an excess adiposity increased the risk of severe disability after ischemic stroke. Since BMI also reflects total lean mass, it is risky to conclude that there is a protective effect of obesity alone in the functional recovery after stroke; nevertheless, it is possible that a minimum body mass is necessary to prevent severe disability in stroke survivors [23].

Contradictory results were reported in study from 2007 published in American Journal of Medicine and Rehabilitation, showing that the functional improvement scores in normal weighted patients were better than those in overweight/obese patients [24].

In a retrospective cohort study on 53,104 stroke patients from the Danish Stroke Register, data on BMI, age, sex, civil status, stroke severity, stroke subtype, a predefined cardiovascular profile, and socioeconomic status became available. This reported no evidence of an obesity paradox in patients with stroke reported. However stroke occurred at a significantly younger age in patients with higher BMI.

More recently, study analyzed 451 patients hospitalized for ischemic stroke and found that BMI on admission had no relationship to functional recovery on discharge [25]. Most likely, the association between higher BMI and favorable functional recovery might be influenced by stroke severity because patients with high BMI seemed to have had less severe strokes [20] and more lacunar infarctions [26]. 


\section{Depression and Inflammation}

Major depressive disorder (MDD) is a severe psychiatric illness that is associated with significant morbidity and mortality. About one in six individuals will succumb to clinical depression during their lifetime [27]. In addition to mortality associated with suicide, depressed patients are more likely to develop coronary artery disease and type 2 diabetes [28]. Depression also complicates the prognosis of other chronic diseases [29,30]. However, biological mechanisms underlying depression remains poorly understood due to lack of biomarkers, relatively low rates of heritability, and heterogeneity of precipitating factors, including stress $[27,31,32]$.

Despite advances in the treatment of major depression, one-third of depressed patients fail to respond to conventional antidepressant medication [33]. One pathophysiologic mechanism hypothesized to contribute to treatment resistance in depression is inflammation. Inflammation has been linked to depression by a number of putative mechanisms involving neuroinflammation, oxidative stress, endothelial nitric oxide synthase uncoupling, and hyperglutamatergia, as well as their relationships to indirect evidence of neurovascular dysfunction in MDD [34].

Recent evidence has shown that MDD is associated with increased levels of inflammatory markers in the periphery. A number of inflammatory biomarkers (including inflammatory cytokines, acute phase proteins, chemokines, and adhesion molecules) in the periphery have been found to be reliably elevated in one third of all depressed patients with a decreased likelihood of response to conventional antidepressants [35-37]. Conversely, patients treated with cytokines for various illnesses are at increased risk of developing major depressive illness [38]. A recent study reported that treatment-resistant depression (TRD) who have highly increased inflammation (i.e. elevated baseline hs-CRP concentration) responded preferentially to infliximab while infliximab-treated participants with a low level of inflammation appeared to do worse than placebo-treated participants [39]. Of note, increased inflammatory markers in depressed patients have also been associated and may also be associated with remitted stages of depression in response to treatment with conventional antidepressant medications [36,40-44]. Neuroinflammation has been associated with greater rates of major depression. On a background of systemic inflammation, proinflammatory cytokines can access the central nervous system and interfere with serotonin metabolism, and reduce both synaptic plasticity and hippocampal neurogenesis $[45,46]$. Behavioral consequences of these effects of the immune system on the brain include depression [39,47]. Cross-sectional [48-50] and prospective [51-53] epidemiological studies have focused on peripheral inflammatory markers, such as cytokines, on the assumption that peripheral inflammatory markers are etiological factors in the development of depressive symptoms [54,44] as well as induce neurotransmitter changes in the brain as seen in depression [55]. The most consistent finding has been the association of elevated cytokines IL-6 and Il-8 with depressive symptoms [38,48-50,56]. Specifically, there was a significant linear relationship between increasing levels of IL-6 and depressive symptoms at baseline, whereas IL- 8 was associated with depressed symptoms at baseline and at 2 years follow-up [44]. More recently, a prospective association of IL-1b and interleukin 1 receptor antagonist (IL1ra) with depressive symptoms in the elderly was also suggested [51,52].

Patients undergoing cytokine therapy are at increased risk of developing major depressive illnesses. For example, IFN-alpha has been frequently associated with significant psychiatric morbidity, notably in the form of the development of major depression in up to 45 percent of patients [57-59]. This findings strongly support the inflammatory hypothesis in the pathophysiology of depression.

Successful antidepressant treatment may reduce proinflammatory markers by improving perfusion or restore endothelial function [35,60,61]. Etanercept, a soluble tumor necrosis factor-a receptor, and celecoxib, a cyclo-oxygenase- 2 inhibitor, may reduce depressive symptoms in patients with inflammatory diseases $[62,63]$ and infliximab may improve depression in patients with greater pre-treatment inflammation [39]. 


\section{Microglia, synaptic plasticity and depressive behaviour}

A large body of post-mortem [64,65] and neuroimaging [64,66] studies of depressed patients have reported reductions in grey-matter volume and glial density in the prefrontal cortex and the hippocampus, regions thought to mediate the cognitive aspects of depression. Further, the Wnt $/ \beta$-catenin pathway -that is implicated in synaptic plasticity it is downregulated in major depression and upregulated after antidepressant treatment. Likewise, the mTOR pathway which is controling synaptic plasticity, is disrupted in major depression, and the target of some drugs with fast-acting potential antidepressant action. Finally, recent studies suggest that microglia may play a role in synaptic remodeling and plasticity in the healthy brain [67-72]. Furthermore, disrupting microglia-specific CR3/C3 signaling resulted in sustained deficits in synaptic connectivity [72]. Taken together these results highly suggest that there is a deep connection between inflammation, microglia, neuroplasticity and mood regulation. However, it remains less clear what role microglia play in the uninjured brain. A recent report has shown that in the normal brain microglia synaptic remodeling and plasticity in the healthy brain and and play a major role in synaptic pruning during postnatal development in mice by actively engulfing synaptic material [69]. Signaling through a phagocytic receptor, complement receptor 3 (CR3/CD11b$\mathrm{CD} 18 / \mathrm{Mac}-1)$ is a key molecular mechanism underlying engulfment of synapses. CR3 is expressed on the surface of microglia and its ligand, complement component $\mathrm{C} 3$ is localized to synaptically-enriched regions. Conversely, disruption of CR3/C3 signaling was specific to microglia in the CNS and resulted in sustained deficits in brain wiring and structural remodeling.

\section{Depression and Aging}

The prevalence of depression and cognitive dysfunction is particularly elevated in the elderly and obese subjects. Aging is one of the most challenging public health issue facing the developed countries today. With the growth in aged population, there has been a growing interest to promote successful aging and to reduce disparities in attaining maximum healthy life expectancy [73].

Depression is an independent risk factor for early mortality [74]. Patients with major depression have an increased onset risk of aging-related diseases affecting the cardiovascular, cerebrovascular, neuroendocrine, metabolic, and immune systems [75-78]. Depression can thus significantly compromise successful aging defined subjectively as freedom from chronic disease and disability, along with high physical and cognitive functioning and social engagement $[79,80]$.

Among elderly individuals, depressive symptoms are common and burdensome $[27,81,82]$. In a given year, between 1 to $2 \%$ of individuals over the age of 65 will meet the criteria for major depressive disorder [83]. Even though this 12-month prevalence seems quite low compared to the about $6 \%$ observed in adults, several parameters have to be take into account. First, it has recently been demonstrated that the apparently lower prevalence estimates of depression in older adults might be biased by incorrect inclusions of individuals, notably patients with sub-threshold hypomania; and to a lesser extent, to the increase in general medical condition depressive disorders with age. Second, another $15-25 \%$ of elders experience depressive symptoms that, while not meeting criteria for major depressive disorder, do cause significant distress and interfere with daily functioning [84]. Third, with the ongoing demographic changes, an ever increasing number of older adults with mental illnesses, notably late life depression, is expected [85]. Overall, among the aging population, individuals experiencing late life depression display greater functional disability [86] and cognitive decline than healthy ones [87].

Normal aging is a situation characterized by a chronic low-grade, pro-inflammatory state [88], with an over-expression of systemic inflammatory factors, including pro-inflammatory cytokines [89,90]. Ageassociated inflammation in the brain manifests primarily by the chronic activation of perivascular and 
parenchymal macrophages/microglia expressing proinflammatory cytokines and an incrased number of astrocytes [91-93].

Given the potential role of inflammation in psychopathology, it is thus highly possible that chronically activated inflammatory signals in aging may contribute to increased vulnerability to neuropsychiatric disorders [94]. Inflammation in obese women is associated with increased concentrations of inflammatory markers (IL-6, CRP and adipokines) that correlated with increased symptoms of depression and anxiety [95]. Conversely, removal of fat tissue surgically was associated with reduced inflammation [96,97].

\section{Post-stroke depression}

Emerging evidence suggests that stroke and traumatic brain injury confer vulnerability to a late-onset of neuropsychaitric and neurocognitive symptoms [98,99]. Brain injury initiates an exaggerated neuroinflammation by activation of an immune-reactive microglial population as a possible triggering mechanism for the development of depressive-like behavior after injury that may last for weeks and months after the event [99]. Importantly, a recent meta-analysis found that the frequency of depressive symptoms even tends to increase in the long-term phase of recovery [100]. Depression persists after 20 months in $34 \%$ of elderly patients with acute stroke and has been linked to both worse cognitive and physical outcome [101].

Post-stroke depression (PSD) has been shown to increase mortality for more than 5 years after stroke [102]. Emotional distress caused by stroke-induced motor disabilities may contribute to the development of PSD. However, other non-psychological factors such as the ischemia-induced brain lesion itself and/or secondary degenerative changes may play a major etiological role. Despite the fact that a high proportion of stroke patients develop mood disorders, the mechanisms underlying PSD have so far received little attention from the field of neurobiology. One major factor involving the development of post-stroke depression an age-related microglia activation in response to stroke.

Persistent neuronal death causes a prolonged neuroinflammatory response in the infarcted area and may contribute substantially to post-stroke depression. After stroke and traumatic brain injury microglia move toward the site of damage and engulf and clear damaged cellular debris $[68,103,104]$. Previously we have shown that aged rats showed a fulminant microglia reaction during the acute phase of stroke that persists for weeks thereafter $[99,105,106]$. Since microglia has been involved in scavenging synapses, these findings suggest that CR3/C3 signaling is a major determinant of post-stroke depression therefore a major target of intervention.

\section{Conclusions}

Worldwide cerebrovascular diseases are increasing in parallel with modernization, changes in lifestyle, and the growing elderly population. Understanding how aging and life style precipitate the development of cerebrovascular diseases is fundamental for prevention, diagnosis and for the development of safe and efficient therapies. Recent work suggest that perfusion deficits in the elderly can trigger microglial activation and subsequent neuroinflammation and shifts the CNS into a proinflammatory state ultimately resulting in demyelination and neurodegeneration.

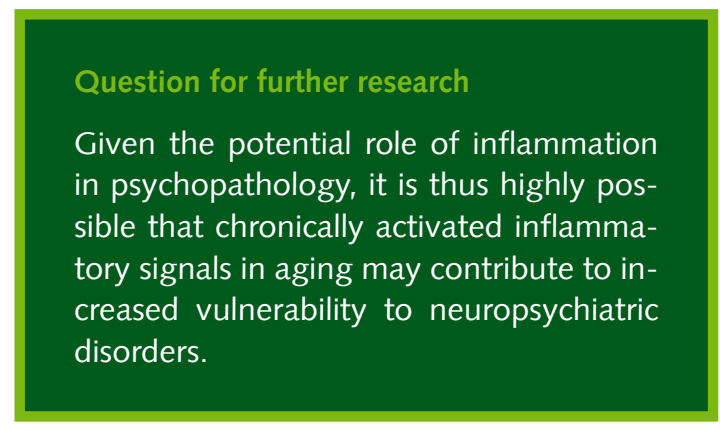




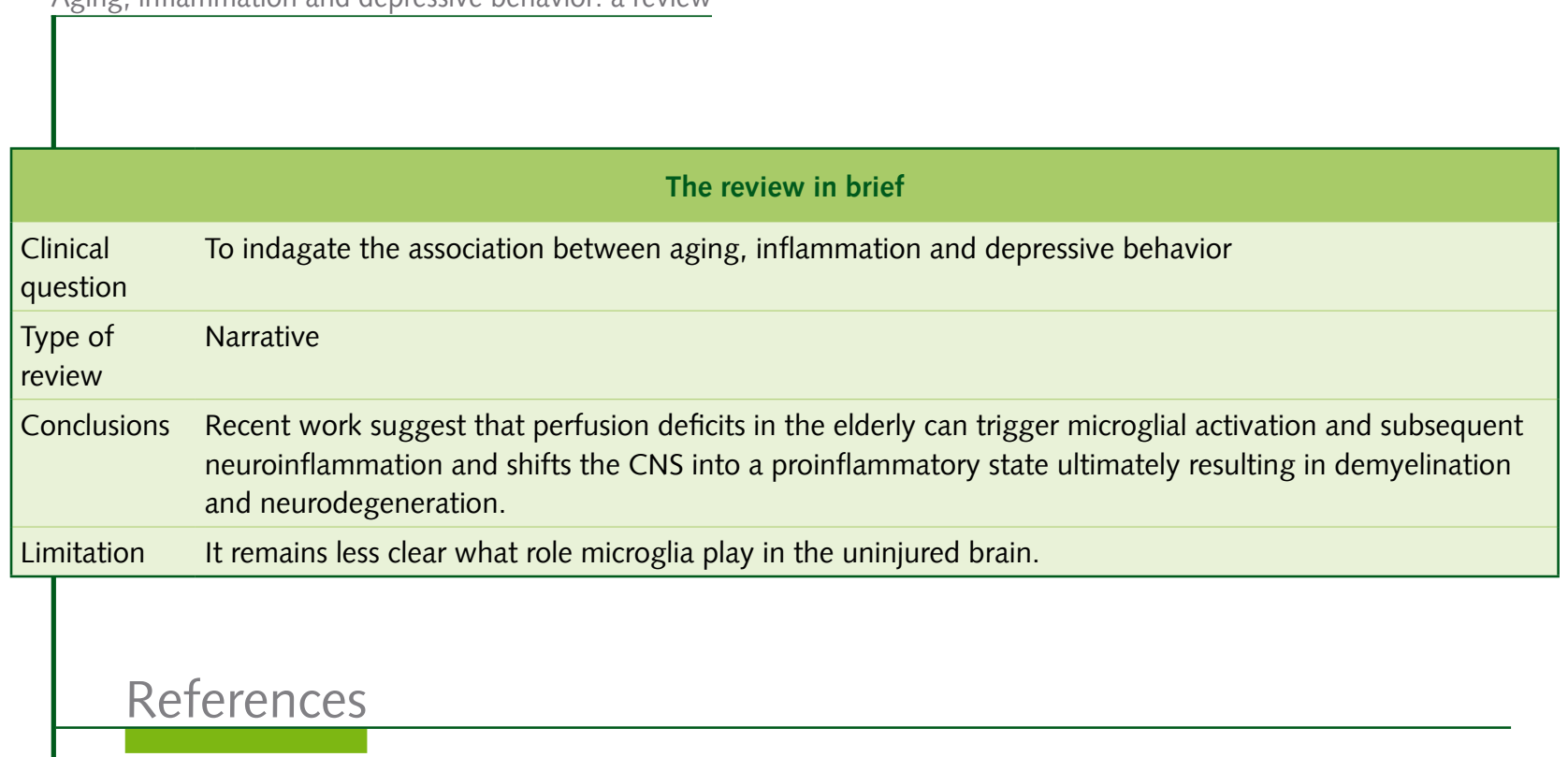

1. Olesen J, Gustavsson A, Svensson M, et al.; CDBE2010 study group. The economic cost of brain disorders in Europe. Eur J Neurol 2012; 19: 155-62; http://dx.doi.org/10.1111/j.14681331.2011.03590.x

2. Sivenius J, Torppa J, Tuomilehto J, et al. Modelling the burden of stroke in Finland until 2030. Int J Stroke 2009; 4: 340-5; http://dx.doi.org/10.1111/j.1747-4949.2009.00330.x

3. Bonita R, Beaglehole R. Recovery of motor function after stroke. Stroke 1988; 19: 1497-500; http:// dx.doi.org/10.1161/01.STR.19.12.1497

4. Burn J, Dennis M, Bamford J, et al. Long-term risk of recurrent stroke after a first-ever stroke. The Oxfordshire Community Stroke Project. Stroke 1994; 25: 333-7; http://dx.doi.org/10.1161/01. STR.25.2.333

5. Appelros P, Nydevik I, Viitanen M. Poor Outcome After First-Ever Stroke. Predictors for Death, Dependency, and Recurrent Stroke Within the First Year. Stroke 2002; 34: 122-6; http://dx.doi. org/10.1161/01.STR.0000047852.05842.3C

6. Donnan GA, Davis SM. Breaking the $3 \mathrm{~h}$ barrier for treatment of acute ischaemic stroke. Lancet Neurol 2008; 7: 981-2; http://dx.doi.org/10.1016/S1474-4422(08)70230-8

7. Murray C, Sanderson DJ, Barkus C, et al. Systemic inflammation induces acute working memory deficits in the primed brain: Relevance for delirium. Neurobiol Aging 2010; 33: 603-6; http://dx.doi. org/10.1016/j.neurobiolaging.2010.04.002

8. Buga AM, Di Napoli M, Popa-Wagner A. Preclinical models of stroke in aged animals with or without comorbidities: role of neuroinflammation. Biogerontology 2013, 14: 651-62; http://dx.doi. org/10.1007/s10522-013-9465-0

9. Popa-Wagner A, Buga AM, Tica AA, et al. Perfusion deficits, inflammation and aging precipitate depressive behaviour. Biogerontology 2014, 15: 439-48; http://dx.doi.org/10.1007/s10522-014-9516-1

10. Allison DJ, Ditor DS. The common inflammatory etiology of depression and cognitive impairment: a therapeutic target. J Neuroinflammation 2014, 11: 151; http://dx.doi.org/10.1186/s12974-0140151-1

11. Olefsky JM, Glass CK. Macrophages, inflammation, and insulin resistance. Annu Rev Physiol 2010; 72: 219-46; http://dx.doi.org/10.1146/annurev-physiol-021909-135846

12. Poulsen P, Ohm Kyvik K, Vaag A, et al. Heritability of Type II (non-insulin-dependent) diabetes mellitus and abnormal glucose tolerance \pm a population-based twin study. Diabetologia 1999; 42: 139-45; http://dx.doi.org/10.1007/s001250051131

13. Cornelis MC, Hu FB. Gene-environment interactions in the development of type 2 diabetes: recent progress and continuing challenges. Annu Rev Nutr 2012; 32:245-259; http://dx.doi.org/10.1146/ annurev-nutr-071811-150648 
14. Kim JG, Mandal PK, Choi KD, et al. Beneficial dietary effect of turmeric and sulphur on weight gain, fat deposition and lipid profile of serum and liver in rats. J Food Sci Technol 2014; 51:774-9; http://dx.doi.org/10.1007/s13197-011-0569-8

15. Olsen TS, Dehlendorff C, Petersen HG, et al. Body mass index and poststroke mortality. Neuroepidemiology 2008; 30: 93-100; http://dx.doi.org/10.1159/000118945

16. Towfighi A, Ovbiagele B. The impact of body mass index on mortality after stroke. Stroke 2009; 40 : 2704-8; http://dx.doi.org/10.1161/STROKEAHA.109.550228

17. Vemmos K, Ntaios G, Spengos K, et al. Association between obesity and mortality after acute first-ever stroke: the obesity-stroke paradox. Stroke 2011; 42: 30-6; http://dx.doi.org/10.1161/ STROKEAHA.110.593434

18. Ovbiagele B, Bath PM, Cotton D, et al. Obesity and recurrent vascular risk after a recent ischemic stroke. Stroke 2011; 42: 3397-402; http://dx.doi.org/10.1161/STROKEAHA.111.624957

19. Andersen KK, Olsen TS. The obesity paradox in stroke: lower mortality and lower risk of readmission for recurrent stroke in obese stroke patients. Int J Stroke 2015; 10: 99-104; http:// dx.doi.org/10.1111/ijs.12016

20. Ryu WS, Lee SH, Kim CK, et al. Body mass index, initial neurological severity and long-term mortality in ischemic stroke. Cerebrovasc Dis 2011; 32: 170-6; http://dx.doi. org/10.1159/000328250

21. Zhao L, Du W, Zhao X, et al. Favorable functional recovery in overweight ischemic stroke survivors: findings from the China National Stroke Registry. J Stroke Cerebrovasc Dis 2014; 23: e201-6; http:// dx.doi.org/10.1016/j.jstrokecerebrovasdis.2013.10.002

22. Burke DT, Al-Adawi S. Effect of Body Mass Index on Stroke Rehabilitation. J Stroke Cerebrovasc Dis. 2014; 23: e201-6; http://dx.doi.org/10.1016/j.apmr.2014.01.019

23. Chiquete E, Cantú-Brito C. Obesity paradox and functional recovery in first-ever acute ischemic stroke survivors: The PREMIER study. Rev Neurol 2010; 51: 705-13

24. Kalichman L, Rodrigues B, Gurvich D, et al. Impact of patient's weight on stroke rehabilitation results. Am J Phys Med Rehabil 2007; 86: 650-5; http://dx.doi.org/10.1097/PHM.0b013e318115f41b

25. Razinia T, Saver JL, Liebeskind DS, et al. Body mass index and hospital discharge outcomes after ischemic stroke. Arch Neurol 2007; 64: 388-91; http://dx.doi.org/10.1001/archneur.64.3.388

26. Tanizaki Y, Kiyohara Y, Kato I, et al. Incidence and risk factors for subtypes of cerebral infarction in a general population: the Hisayama study. Stroke 2000; 31: 2616-22; http://dx.doi.org/10.1161/01. STR.31.11.2616

27. Kessler D, Sharp D, Lewis G. Screening for depression in primary care. Br J Gen Pract 2005; 55 : 659-60

28. Knol MJ, Twisk JW, Beekman AT, et al. Depression as a risk factor for the onset of type 2 diabetes mellitus. A meta-analysis. Diabetologia 2006; 49: 837-84; http://dx.doi.org/10.1007/s00125-006-0159-x

29. Evans J, Heron J, Lewis G, et al.; ALSPAC study team. Negative self-schemas and the onset of depression in women: longitudinal study. Negative self-schemas and the onset of depression in women: longitudinal study. Br J Psychiatry 2005; 186: 302-7; http://dx.doi.org/10.1192/ bjp.186.4.302

30. Gildengers AG, Whyte EM, Drayer RA, et al. Medical burden in late-life bipolar and major depressive disorders. Am J Geriatr Psychiatry 2008; 16: 194-200; http://dx.doi.org/10.1097/ JGP.0b013e318157c5b1

31. Krishnan V, Nestler EJ. The molecular neurobiology of depression. Nature 2008; 455: 894-902; http://dx.doi.org/10.1038/nature07455

32. Trivedi MH, Fava M, Marangell LB, et al. Use of treatment algorithms for depression. Prim Care Companion. J Clin Psychiatry 2006; 8: 291-8; http://dx.doi.org/10.4088/PCC.v08n0506 
33. Rush AJ, Trivedi MH, Wisniewski SR, et al. Bupropion-SR, sertraline, or venlafaxine-XR after failure of SSRIs for depression. N Engl J Med 2006; 354: 1231-42; http://dx.doi.org/10.1056/ NEJMoa052963

34. Najjar S, Pearlman DM, Devinsky O, et al. Neurovascular unit dysfunction with blood-brain barrier hyperpermeability contributes to major depressive disorder: a review of clinical and experimental evidence. J Neuroinflammation 2013; 10: 142; http://dx.doi.org/10.1186/1742-2094-10-142

35. Miller AH, Maletic V, Raison CL. Inflammation and its discontents: the role of cytokines in the pathophysiology of major depression. Biol Psychiatry 2009; 65: 732-41; http://dx.doi.org/10.1016/j. biopsych.2008.11.029

36. Lanquillon S, Krieg JC, Bening-Abu-Shach U, et al. Cytokine production and treatment response in major depressive disorder. Neuropsychopharmacology 2000; 22: 370-9; http://dx.doi.org/10.1016/ S0893-133X(99)00134-7

37. Papakostas GI, Fan H, Tedeschini E. Severe and anxious depression: combining definitions of clinical sub-types to identify patients differentially responsive to selective serotonin reuptake inhibitors. Eur Neuropsychopharmacol 2012; 22: 347-55; http://dx.doi.org/10.1016/j.euroneuro.2011.09.009

38. Krishnadas R, Cavanagh J. Depression: an inflammatory illness? J Neurol Neurosurg Psychiatry 2012; 83: 495-502; http://dx.doi.org/10.1136/jnnp-2011-301779

39. Raison CL, Rutherford RE, Woolwine BJ, et al. A randomized controlled trial of the tumor necrosis factor antagonist infliximab for treatment-resistant depression: the role of baseline inflammatory biomarkers. JAMA Psychiatry 2013; 70: 31-41; http://dx.doi.org/10.1001/2013.jamapsychiatry.4

40. Sluzewska A, Sobieska M, Rybakowski JK. Changes in acute-phase proteins during lithium potentiation of antidepressants in refractory depression. Neuropsychobiology 1997; 35: 123-7; http://dx.doi.org/10.1159/000119332

41. Nemeroff CB, Heim CM, Thase ME, et al. Differential responses to psychotherapy versus pharmacotherapy in patients with chronic forms of majordepression and childhood trauma. Proc Natl Acad Sci U S A 2003; 100:14293-6; http://dx.doi.org/10.1073/pnas.2336126100

42. Danese A, Pariante CM, Caspi A, Taylor A, Poulton R. Childhood maltreatment predicts adult inflammation in a life-course study. Proc Natl Acad Sci U S A 2007; 104: 1319-24; http://dx.doi. org/10.1073/pnas.0610362104

43. Danese A, Moffitt TE, Pariante CM, et al. Elevated inflammation levels in depressed adults with a history of childhood maltreatment. Arch Gen Psychiatry 2008; 65: 409-15; http://dx.doi. org/10.1001/archpsyc.65.4.409

44. Baune BT, Smith E, Reppermund S, et al. Inflammatory biomarkers predict depressive, but not anxiety symptoms during aging: the prospective Sydney Memory and Aging Study. Psychoneuroendocrinology 2012; 37: 1521-30; http://dx.doi.org/10.1016/j.psyneuen.2012.02.006

45. Caraci F, Copani A, Nicoletti F, et al. Depression and Alzheimer's disease: neurobiological links and common pharmacological targets. Eur J Pharmacol 2010; 626: 64-71; http://dx.doi.org/10.1016/j. ejphar.2009.10.022

46. Maes M, Yirmyia R, Noraberg J, et al. The inflammatory \& neurodegenerative (I\&ND) hypothesis of depression: leads for future research and new drug developments in depression. Metab Brain Dis. 2009; 24: 27-53; http://dx.doi.org/10.1007/s11011-008-9118-1

47. Capuron, L, Miller, A.H. Immune system to brain signaling: neuropsychopharmacological implications.Pharmacol.Ther2011;130:226-38;http://dx.doi.org/10.1016/j.pharmthera.2011.01.014

48. Penninx BW, Kritchevsky SB, Yaffe K, et al. Inflammatory markers and depressed mood in older persons: results from the health, aging and body composition study. Biol Psychiatry 2003; 54: 56672; http://dx.doi.org/10.1016/S0006-3223(02)01811-5

49. Tiemeier H, Hofman A, van Tuijl HR, et al. Inflammatory proteins and depression in the elderly. Epidemiology 2003; 14: 103-7; http://dx.doi.org/10.1097/00001648-200301000-00025 
50. Bremmer MA, Beekman AT, Deeg DJ, et al. Inflammatory markers in late-life depression: results from a population-based study. J Affect. Disord 2008; 106: 249-55; http://dx.doi.org/10.1016/j. jad.2007.07.002

51. van den Biggelaar AH, Gussekloo J, de Craen AJ, et al. Inflammation and interleukin-1 signaling network contribute to depressive symptoms but not cognitive decline in old age. Exp Gerontol 2007; 42: 693-701; http://dx.doi.org/10.1016/j.exger.2007.01.011

52. Milaneschi Y, Corsi AM, Penninx BW, et al. Interleukin-1 receptor antagonist and incident depressive symptoms over 6 years in older persons: the InCHIANTI study. Biol Psychiatry 2009; 65: 973-8; http://dx.doi.org/10.1016/j.biopsych.2008.11.011

53. Stewart JW, McGrath PJ, Quitkin FM, et al. DSM-IV depression with atypical features: is it valid? Neuropsychopharmacology 2009; 34: 2625-32; http://dx.doi.org/10.1038/npp.2009.99

54. Dantzer R, O'Connor JC, Freund GG, et al. From inflammation to sickness and depression: when the immune system subjugates the brain. Nat Rev Neurosci 2008; 9: 46-56; http://dx.doi. org/10.1038/nrn2297

55. Anisman H, Merali Z, Hayley S. Neurotransmitter, peptide and cytokine processes in relation to depressive disorder: comorbidity between depression and neurodegenerative disorders. Prog Neurobiol 2008; 85: 1-74; http://dx.doi.org/10.1016/j.pneurobio.2008.01.004

56. Dentino AN, Pieper CF, Rao MK, et al. Association of interleukin-6 and other biologic variables with depression in older people living in the community. J Am Geriatr Soc 1999; 47: 6-11

57. Musselman DL, Miller AH, Porter MR, et al. Higher than normal plasma interleukin-6 concentrations in cancer patients with depression: preliminary findings. Am J Psychiatry 2001; 158: 1252-7; http://dx.doi.org/10.1176/appi.ajp.158.8.1252

58. Raison CL, Demetrashvili M, Capuron L, et al. Neuropsychiatric adverse effects of interferon-alpha: recognition and management. CNS Drugs 2005; 19: 105-23; http://dx.doi.org/10.2165/00023210200519020-00002

59. Capuron L, Miller AH. Cytokines and psychopathology: lessons from interferon-alpha. Biol Psychiatry 2004; 56: 819-24; http://dx.doi.org/10.1016/j.biopsych.2004.02.009

60. Ghiadoni L, Virdis A, Magagna A, et al. Effect of the angiotensin II type 1 receptor blocker candesartan on endothelial function in patients with essential hypertension. Hypertension 2000; 35: 501-6; http://dx.doi.org/10.1161/01.HYP.35.1.501

61. Nagata Y, Takahashi A, Ohnishi K, et al. Effect of rapamycin, an mTOR inhibitor, on radiation sensitivity of lung cancer cells having different p53 gene status. Int J Oncol 2010; 37: 1001-10; http://dx.doi.org/10.3892/ijo_00000751

62. Tyring S, Gottlieb A, Papp K, et al. Etanercept and clinical outcomes, fatigue, and depression in psoriasis: double-blind placebo-controlled randomised phase III trial. Lancet 2006; 367: 29-35; http://dx.doi.org/10.1016/S0140-6736(05)67763-X

63. Kekow J, Moots RJ, Emery P, et al. Patient-reported outcomes improve with etanercept plus methotrexate in active early rheumatoid arthritis and the improvement is strongly associated with remission: the COMET trial. Ann Rheum Dis 2010; 69: 222-5; http://dx.doi.org/10.1136/ ard.2008.102509

64. Drevets WC. Neuroimaging and neuropathological studies of depression: implications for the cognitive-emotional features of mood disorders. Curr Opin Neurobiol 2001; 11: 240-9; http:// dx.doi.org/10.1016/S0959-4388(00)00203-8

65. Sheline YI. Neuroimaging studies of mood disorder effects on the brain. Biol Psychiatry 2003;54: 338-52; http://dx.doi.org/10.1016/S0006-3223(03)00347-0

66. Harrison RV, Harel N, Panesar J, et al. Blood capillary distribution correlates with hemodynamicbased functional imaging in cerebral cortex. Cereb Cortex 2002; 12: 225-33; http://dx.doi. org/10.1093/cercor/12.3.225 
67. Davalos D, Grutzendler J, Yang G, et al. ATP mediates rapid microglial response to local brain injury in vivo. Nat Neurosci 2005; 8: 752-8; http://dx.doi.org/10.1038/nn1472

68. Nimmerjahn A, Kirchhoff F, Helmchen F. Resting microglial cells are highly dynamic surveillants of brain parenchyma in vivo. Science 2005; 308: 1314-18; http://dx.doi.org/10.1126/ science. 1110647

69. Paolicelli RC, Bolasco G, Pagani F, et al. Synaptic pruning by microglia is necessary for normal brain development. Science 2011; 333: 1456-8; http://dx.doi.org/10.1126/science.1202529

70. Tremblay MÈ, Lowery RL, Majewska AK. Microglial interactions with synapses are modulated by visual experience. PLoS Biol 2010; 8: e1000527; http://dx.doi.org/10.1371/journal.pbio.1000527

71. Wake H, Moorhouse AJ, Jinno S, et al. Resting microglia directly monitor the functional state of synapses in vivo and determine the fate of ischemic terminals. J Neurosci 2009; 29: 3974-80; http:// dx.doi.org/10.1523/JNEUROSCI.4363-08.2009

72. Schafer DP, Lehrman EK, Kautzman AG, et al. Microglia sculpt postnatal neural circuits in an activity and complement-dependent manner. Neuron 2012; 74: 691-705; http://dx.doi. org/10.1016/j.neuron.2012.03.026

73. Depp CA, Harmell A, Vahia IV. Successful cognitive aging. Curr Top Behav Neurosci 2012; 10: 35 50; http://dx.doi.org/10.1007/7854_2011_158

74. Gump BB, Matthews KA, Eberly LE, et al.; MRFIT Research Group. Depressive symptoms and mortality in men: results from the Multiple Risk Factor Intervention Trial. Stroke 2005; 36: 98-102; http://dx.doi.org/10.1161/01.STR.0000149626.50127.d0

75. McIntyre RS, Soczynska JK, Konarski JZ, et al. Should Depressive Syndromes Be Reclassified as "Metabolic Syndrome Type II"? Ann Clin Psychiatry 2007; 19: 257-64; http://dx.doi. org/10.1080/10401230701653377

76. Bauer ME. Chronic stress and immunosenescence: a review. Neuroimmunomodulation 2008; 15: 241-50; http://dx.doi.org/10.1159/000156467

77. Wolkowitz OM, Epel ES, Reus VI, et al. Depression gets old fast: do stress and depression accelerate cell aging? Depress Anxiety 2010; 27: 327-38; http://dx.doi.org/10.1002/da.20686

78. Warsch JR, Rundek T, Paik MC, et al. Association between northern Manhattan study global vascular risk score and successful aging. J Am Geriatr Soc 2013; 61: 519-24; http://dx.doi. org/10.1111/jgs.12166

79. Berkman LF, Seeman TE, Albert M, et al. High, usual and impaired functioning in communitydwelling older men and women: findings from the MacArthur foundation research network on successful aging. J Clin Epidemiol 1993; 46: 1129-40; http://dx.doi.org/10.1016/08954356(93)90112-E

80. Jeste DV, Savla GN, Thompson WK, et al. Association between older age and more successful aging: critical role of resilience and depression. Am J Psychiatry 2013; 170: 188-96; http://dx.doi. org/10.1176/appi.ajp.2012.12030386

81. Kessler RC, Birnbaum HG, Shahly V, et al. Age differences in the prevalence and co-morbidity of DSM-IV major depressive episodes: results from the WHO World Mental Health Survey Initiative. Depress Anxiety 2010; 27: 351-64; http://dx.doi.org/10.1002/da.20634

82. Luppa M, Konig HH, Heider D, et al. Direct costs associated with depressive symptoms in late life: a 4.5-year prospective study. Int Psychogeriatr 2013; 25: 292-302; http://dx.doi.org/10.1017/ S1041610212001688

83. Kessler RC, Berglund P, Demler O, et al. The epidemiology of major depressive disorder: results from the National Comorbidity Survey Replication (NCS-R). JAMA 2003; 289: 3095-105; http:// dx.doi.org/10.1001/jama.289.23.3095 
84. Brevik EJ, Eikeland RA, Lundervold AJ. Subthreshold depressive symptoms have a negative impact on cognitive functioning in middle-aged and older males. Front Psychol 2013; 4: 309; http://dx.doi. org/10.3389/fpsyg.2013.00309

85. Grav S, Stordal E, Romild UK, et al. The relationship among neuroticism, extraversion, and depression in the HUNT Study: in relation to age and gender. Issues Ment Heal Nurs 2012; 33: 777 85; http://dx.doi.org/10.3109/01612840.2012.713082

86. Dombrovski AY, Lenze EJ, Dew MA, et al. Maintenance treatment for old-age depression preserves health-related quality of life: a randomized, controlled trial of paroxetine and interpersonal psychotherapy. J Am Geriatr Soc 2007; 55: 1325-32; http://dx.doi.org/10.1111/j.15325415.2007.01292.x

87. Lenze EJ, Schulz R, Martire LM, et al. The course of functional decline in older people with persistently elevated depressive symptoms: longitudinal findings from the cardiovascular health study. J Am Geriatr Soc 2005; 53: 569-75; http://dx.doi.org/10.1111/j.1532-5415.2005.53202.x

88. Bruunsgaard H, Pedersen M, Pedersen BK. Aging and proinflammatory cytokines. Curr Opin Hematol 2001; 8: 131-6; http://dx.doi.org/10.1097/00062752-200105000-00001

89. Fagiolo U, Cossarizza A, Santacaterina $S$, et al. Increased cytokine production by peripheral blood mononuclear cells from healthy elderly people. Ann N Y Acad Sci 1992; 663: 490-3; http://dx.doi. org/10.1111/j.1749-6632.1992.tb38712.x

90. Fagiolo U, Cossarizza A, Scala E, et al. Increased cytokine production in mononuclear cells of healthy elderly people. Eur J Immunol 1993; 23: 2375-8; http://dx.doi.org/10.1002/eji.1830230950

91. Floyd RA, Hensley K, Jaffery F, et al. Increased oxidative stress brought on by pro-inflammatory cytokines in neurodegenerative processes and the protective role of nitrone-based free radical traps. Life Sci 1999; 65: 1893-9; http://dx.doi.org/10.1016/S0024-3205(99)00443-9

92. Ye SM, Johnson RW. Increased interleukin- 6 expression by microglia from brain of aged mice. $J$ Neuroimmunol 1999; 93: 139-48; http://dx.doi.org/10.1016/S0165-5728(98)00217-3

93. Akiyama $\mathrm{H}$, Arai T, Kondo $\mathrm{H}$, et al. Cell mediators of inflammation in the Alzheimer disease brain Alzheimer. Dis Assoc Disord 2000; 14: S47-53; http://dx.doi.org/10.1097/00002093-200000001-00008

94. Capuron L, Su S, Miller AH, et al. Depressive symptoms and metabolic syndrome: is inflammation the underlying link? Biol Psychiatry 2008; 64: 896-900; http://dx.doi.org/10.1016/j. biopsych.2008.05.019

95. Capuron L, Poitou C, Machaux-Tholliez D, et al. Relationship between adiposity, emotional status and eating behavior in obese women: role of inflammation. Psychol Med 2011; 41: 1517-28; http:// dx.doi.org/10.1017/S0033291710001984

96. Cancello R, Henegar C, Viguerie N, et al. Reduction of macrophage infiltration and chemoattractant gene expression changes in white adipose tissue of morbidly obese subjects after surgery-induced weight loss. Diabetes 2005; 54: 2277-86; http://dx.doi.org/10.2337/diabetes.54.8.2277

97. Emery CF, Fondow MD, Schneider CM, et al. Gastric bypass surgery is associated with reduced inflammation and less depression: a preliminary investigation. Obes Surg 2007; 17: 759-63; http:// dx.doi.org/10.1007/s11695-007-9140-0

98. Alexopoulos GS. The vascular depression hypothesis: 10 years later. Biol Psychiatry 2006; 60: 13045; http://dx.doi.org/10.1016/j.biopsych.2006.09.006

99. Fenn AM, Gensel JC, Huang Y, et al. Immune activation promotes depression 1 month after diffuse brain injury: a role for primed microglia. Biol Psychiatry 2013; 76: 575-84; http://dx.doi. org/10.1016/j.biopsych.2013.10.014

100. Hackett ML, Anderson CS. Predictors of depression after stroke: a systematic review of observational studies. Stroke 2005; 36: 2296-301; http://dx.doi.org/10.1161/01.STR.0000183622.75135.a4

101. Linden T, Blomstrand C, Skoog I. Depressive disorders after 20 months in elderly stroke patients. A case-control study. Stroke 2007; 38: 1860-3; http://dx.doi.org/10.1161/STROKEAHA.106.471805 
102. Jorge RE, Robinson RG, Arndt S, et al. Mortality and poststroke depression: a placebo-controlled trial of antidepressants. Am J Psychiatry 2003; 160: 1823-9; http://dx.doi.org/10.1176/appi. ajp.160.10.1823

103. Hanisch UK, Kettenmann H. Microglia: active sensor and versatile effector cells in the normal and pathologic brain. Nat Neurosci 2007; 10: 1387-94; http://dx.doi.org/10.1038/nn1997

104. Wakselman S, Béchade C, Roumier A, et al. Developmental neuronal death in hippocampus requires the microglial CD11b integrin and DAP12 immunoreceptor. J Neurosci 2008; 28: 813843; http://dx.doi.org/10.1523/JNEUROSCI.1006-08.2008

105. Badan I, Platt D, Kessler C, et al. Temporal dynamics of degenerative and regenerative events associated with cerebral ischemia in aged rats. Gerontology 2003; 49: 356-65; http://dx.doi. org/10.1159/000073763

106. Buga AM, Scholz CJ, Kumar S, et al. Identification of new therapeutic targets by genome-wide analysis of gene expression in the ipsilateral cortex of aged rats after stroke. PLoS One 2012; 7: e50985; http://dx.doi.org/10.1371/journal.pone.0050985 